\title{
Comprehensive Guidance and Counselling Programmes and Academic Achievement of Secondary School Students in Edo State, Nigeria
}

\author{
OSUMAH, Obaze Agbonluae, Ph.D \\ Department of Guidance and Counselling, Faculty of Education, Ambrose Alli University, Ekpoma, Edo State, Nigeria
}

\begin{abstract}
This study assessed comprehensive guidance and counselling programmes and academic achievement of secondary school students in Edo State, Nigeria. Four research questions and four hypotheses guided the study. This was a correlation study based on survey research design. A sample of two thousand, two hundred secondary school students in Edo State, Nigeria were selected for the study. A validated instrument titled "Comprehensive Guidance and Counselling Programmes and Students' Academic Achievement Questionnaire (CGCPSAAQ)" was used for collection of data for the study. The instrument was administered on the participants by the researcher and five research assistants specifically trained for the purpose. Data collected were analyzed using t-test and Pearson Product Moment Correlation Coefficient (PPMCC). The analyses yielded the following results: that there was significant relationship between comprehensive guidance and counselling programmes and academic achievement of students in secondary schools in Edo State, Nigeria and the significant relationship between comprehensive guidance programmes and achievement outcomes of secondary school students in Edo State, Nigeria was gender, school location and school type based. Based on the findings of the study, the following recommendations among others were made: government should put in place comprehensive guidance and counselling programmes in all secondary schools and qualified guidance counsellors who are the drivers of counselling programmes should be employed in all secondary schools in Edo State, Nigeria.
\end{abstract}

Keywords: Guidance and counselling programmes, achievement outcomes, students.

\section{INTRODUCTION}

$\mathrm{E}$ ducation is development. It is a critical factor of human development. The Federal Republic of Nigeria (2004), states that education serves as the pinnacle of intellectual activities that guarantee the worth, development and existence of individuals and societies.

Nigeria's education system is based on the (1)-6-3-34 formula: One year pre-primary education, six years primary, three years junior secondary, three years senior secondary, and a minimum of four year tertiary education. The model had been used successfully in China, Germany and Ghana before Nigeria adopted it in 1989 (Ekundayo (2019).

Education improves the quality of lives of the people. Hawkins (2002) observes that education is aimed at providing a form where teachers and scholars are able to evaluate challenges facing the society from a balanced and comparative socio-economic perspective. Education plays a crucial role in securing economic and social progress. Education is expected to prepare and equip the youth of the country to play an effective role in a nation's life and building.

The education sector aim at providing an all rounded programme of instruction which are appropriate to the cultural, intellectual and social needs of the students. Schools encourage acceptance and tolerance to the diversity of moral, traditional and religions values and learning institutions aim at fostering a sense of individual responsibility, self-discipline, self-reliance, creative and active lifestyle and respect for self and others.

Education improves the quality of people's lives and may also lead to broad social benefits to individual and society. Education has a vital role in developing the abilities of students. With education expected individual (students) can develop to their full potentials. Indicators of school success in carrying out her task can be seen from the high academic achievement and variety of specialized skills possess by learner and not the least of which involves issues related to academic. While students are required to continue to improve academic achievement, students need to follow the guidance and counselling services in schools to improve achievement outcomes (Federal Republic of Nigeria, 2004).

Academic achievement of students typically refers to either the desired learning objectives or standards that schools and teachers want students to achieve or educational, societal and life affects that result from students being educated. Students outcomes could be intended goals of a course, programme or learning experience; it could also be that student outcomes are the actual results that students either achieve or fail to achieve during their education or later in life. Academic achievement of students in this endeavour means the results achieved by educators and others including results such as standardized-test-scores, test examinations, graduation rates and college-enrolment rates. Generally speaking, students achievement outcomes are consideredeither explicitly or implicitly to be positive or negative by educators. If students are learning what they are expected to 
learn, or graduation rates in a school are rising, these results would generally be viewed as "positive students academic achievement;" conversely, low or declining test scores and high dropout rates would be "negative student academic achievement" (American School Counselling Association, 2005).

Students constantly prepare to overcome the different challenges they encounter throughout their time in school in order to enhance their academic achievement. They often need some type of support, guidance or counselling to improve conditions facing both their educational and the decisions that they have to make about their future (Okobiah and Okorodudu, 2004).

According to Okobiah and Okorodudu (2004) guidance is a program of activities which has provided us with the gateway out of the existing numerous problems in our present age of complex scientific and technological development. Essuman (2010) maintains that guidance and counselling should form an essential part of our educational system. Many students perform poorly because they lack the right attitude to study. Guidance and counselling help students to make decisions, solve problems, and develop positive attitudes towards self and others, establish personal goals, develop educational plans as well as select the related courses based on individual interests and talents and be responsible for one's actions and choices.

Students proceed through different levels of education or grades that prepare them for the educational or professional stages to come, with varying levels of success. Throughout their schooling, students have made important decisions about their future that will shape their educational path or professional career later on. These decisions are especially determined by their achievement outcome performance in school and level of knowledge about the different opportunities available to them. Providing orientation, counselling and guidance services may be determinative for students' academic achievement, selfconfidence, expectations for the future, educational or academic performance, emotional, health and other aspects.

Counselling may help students to navigate through different educational path options and maintain or increase their expectations, commitment and achievement outcomes. There are different services that schools can include to perform these functions aimed at counselling, following up and giving support to students. The most prominent of these is guidance and counselling which monitors students throughout their time in school in order to record, support and guide their studies at all times (Okobiah and Okorodudu, 2004)

There are many different programs and strategies that can be implemented in school settings to provide counselling and guidance services to students. According to the American School Counsellor Association (ASCA) (2005), counsellors provide three main categories of services:
- Individual planning: the different programs that include individual planning consider evaluation and counselling of both students and the group (class) to which they belong. Individual planning activities are designed to help students to develop and carry out their personal, educational and career plans. The counsellor as educational professional coordinates systematic activities during the school designed mainly to help students to prevent situations that could be harmful (like situation of violence, buying mental health problems or dropping out of school), set their personal goals individually and develop plans for their future

- Responsive services: responsive programs or services are characterized by providing special and nonsystematic assistance (more on demand) to students facing problems or difficulties that could interfere with their personal, rational or educational development. Within this category are services offering individual counselling, and counselling for small group, counselling regarding difficult situations, and specific problems and immediate needs.

The objectives of these programs and services vary greatly and may be grouped into three categories:

Academic guidance: these include counselling and guidance programs for students that aim at improving their academic performance and achievement outcomes. Evaluation of these programs measures this impact both with grades and to a lesser extent standardized tests. Counsellors support students directly in their academic life to foster, promote, and increase interpersonal competencies and academic achievement. The counselling departments believe that sound education involves the development of the whole student. This includes the social, emotional, intellectual, and physical aspects of students' lives. Counselling services are accessible to all students and their families. New student orientation focuses on making new students feel welcome and prepared for the academic year.

Academic Counselling designed to help students and parents acquire knowledge of curricular choices, plan a program of studies, and interpret academic opportunities. Career counselling helps students acquire information and plan for appropriate education and training for career choices and post-secondary goals. Educational counselling increases students' awareness of educational opportunities (UNESCO, 2000). It provides students with information on learning styles and study methods as well how their attitudes, interests and work habits affect their educational opportunities (UNESCO, 2000). Through educational Counselling, students are effectively helped to select subjects and career. They are guided on effective study skills. Students are also helped to balanced between the co-curricular and curriculum activities as well as prepare for examination. The purpose of 
educational Counselling is helping student adjust to the school academic environment and consequently actualize their potential in their achievement outcomes and academic performance.

Personal/social guidance: These include programs and services that have an effect on students' behaviour, empowering them to make decisions and show selfconfidence beyond what is related with educational transitions and curriculum. They also have effect on students' emotional state, mental health and self esteem. Personal/social Counselling assists students in developing an understanding of themselves and to respect the rights and needs of others. Individual counselling helps with personal difficulties which impede personal growth, satisfaction, and achievement outcomes or academic success. Personal/ social Counselling deals with emotional distress and behavioural difficulties that arise when individuals struggle to deal with development stages and tasks (UNESCO, 2000). Students are empowered and helped to develop positive attitudes toward themselves (UNESCO, 2000).

Guidance on educational path or professional career: Guidance and counselling services and programs aimed specifically at giving answers and improving skills in educational transitions, as well as providing future guidance both to remaining in school and shifting to the working world (professionalization). These programs are often addressed to secondary school students, but there are also examples of programs applied to universities. Vocational Counselling involves school counsellors having individual contacts with students who they counsel in order to facilitate career development and this helps students to become aware of the many occupations to consider and decide what to do after school (UNESCO, 2000). Professional school counsellors ideally implement all school counselling programes that promote and enhances students' achievement outcomes.

Professional school counselors meet the needs of student in three basic domains: academic development, career development and personal/social development.

School counsellor interventions include individual and group counseling for some students. Example, if a student's behaviour is interfering with his or her academic achievement, the school counsellor may observe that student in a class, provide consultation to teachers and other stakeholders, develop (with the student) a plan to address the behavioural issue(s) and then collaborate to implement and evaluate the plan.

School counsellor interventions for all students include annual academic/career/college access and leading classroom developmental lessons on academic, career/college, and personal/social topics.

In Nigeria, guidance and counselling services are relatively recent. It does not provide the standard of counselling like in the USA or Canada, counselling should be at least include two individuals. The first seeks help and second provides help.

Nwonyuku (2017) carried out a research on the impact of guidance and counselling on performance of secondary schools in Awka South Local Government Area of Anambra State, Nigeria. The study employed two sets of secondary data - guidance and counselling characteristics such as a guidance counsellor size and qualification and secondary school performance indicators such as student enrolment size, student drop out size, and school external examination performance, while teacher size served as control variable over a period of seven years spanning from 2010 to 2016 in order to ascertain the desirability, suitability, utility or goodness of guidance and counselling to the school performance. To achieve this, the study adopted descriptive survey research design. Population of the study was 50 approved students and private secondary schools in Awka South L.G.A. of Anambra State, Nigeria; out of which, a purposive sampling technique was used to select 18 secondary schools. Secondary method data of collection was adopted coupled with the observation and measurement instruments, archived data were collected from Post-Primary School Service Commission headquarters in Awka South Local Government Area. The data collected were analysed statistically in a software E-view version 9.5 using pooled effect of Ordinary Least Square (OLS) multiple regression estimates in a panel data setting in three prediction models to test the underlying assumptions. The study found that guidance and counseling has impact on performance of secondary school secondary students in Awka South Local Government Area of Anambra State, Nigeria. The study also found that there was significant gender difference in the influence between guidance and counselling on academic performance of secondary students in Awka South Local Government Area of Anambra State, Nigeria.

Meta-analyses reviewed showed the effect of guidance and counseling on achievement outcomes of students. Whiston, Tai, Rhardja and Eder (2011), carried out a study on academic, personal/social guidance and counseling on educational path or professional career focused on individual planning and guidance curriculum on elementary to high school students in different year in the United States of America. The measurement of the effect shows overall effect of 0.30 . The effect on guidance services were as follows: Guidance curriculum and care services $=0.35$, individual planning $=0.26$; responsive services $=0.35$; programmes assessment $=0.19$. The effect of guidance and counseling on behaviour and cognitive skills were as follows; general behaviour results $=0.41$.general affective results $=0.19$; attendance $=0.30 ;$ problem-solving skills $=0.96 ;$ social skills $=0.33$; discipline $=0.83$ and perception of academic functioning $=0.17$. The effects of guidance and counselling on socio-emotional aspect of students were as follows: personal social development $=0.24$; anxiety $=0.40$, depression $=0.37$. The effects of guidance and counselling on educational outcomes of students were as follows: grade point 
average $=0.15$. Standardized scores from achievement test $=0.16$ : knowledge of the degree $=0.67$ and other $=0.79$.

Similarly, Erford, Bardhohi, Ross, Gunther, and Durican (2017), carried out a study on effect of personal/social guidance on children and adolescents with behavioural problems from kindergarten to high school in different year in the United State of America. The finding of the study showed overall effect of 0.57 .

In the same vein, Whiston, Brecheisen and Stephen (2003) carried out a study on effect of guidance on educational path or professional career (focusing on strategies) among high school (different years) and elementary school and adults in the United States of America. The findings of the study were as follows: individual guidance $=0.25 ;$ guidance $=0.05 ;$ structural workshop group $=0.20$; classroom $=0.33$; by computer 0.14 and out of school counsellor $=0.04$.

Several studies found that elementary guidance activities have a positive influence on elementary students' academic achievement (Sink and Stroh, 2003)

School counselling interventions have reported success for helping students reduce test anxiety (Check, Reynolds \&. Coy, 2002).

A study of Mussouri High Schools show that schools with more fully implemented model guidance programs had students who were more likely to report that (a) they had earned higher grades, (b) their education was better preparing them for the future, and (c) their school made more career and college information available to them.

Armacost (1990) established that boys handle stress better than girls. Van Der Walt and Knoetze (2004) observed that Guidance and Counselling normally was more effective in socializing boys to be stronger and cope with their own problems than girls. Similarly Makesh and kaji (2014) found that boys adjust to school social environment than girls. Other researches on gender difference in school adjustment has portrayed that girls are better adjusted as compared to boys. Alexitch and Page (1997) established that in Canada, girls were more responsive to university and career information from their counselling teachers than boys. Bruce and Cockreham (2004) found that in America girls to be more tolerant towards rules, more willing to make exceptions and more easily reconciled than boys.

One of the primary challenges for school counsellors and other adults in the school community is how to instill in students love for learning, becoming excited about the adventure of exploration, discovery that leads to achieving one's goals, a sense of fulfillment students need to understand the importance of being motivated to achieve, the relationship of achievement to success in school and the consequences of failing to find the motivation to accomplish something meaningful and significant in their lives (Spark Notes Editors, 2005).

It is against this backdrop that this study assesses comprehensive guidance and counselling and academic achievement of secondary school students in Edo State, Nigeria.

\section{RATIONALE FOR THE STUDY}

Guidance and counselling programmes, (Educational, Vocational, Socio-personal counselling) in secondary schools in Edo state, Nigeria are expected to help students to make decisions, solve problems, develop positive attitudes towards self and others, established personal goals, develop educational plans as well as select the related courses based on individual interests and talents and be responsible for one's actions and choices (Charturvedi, 2007). Counseling is the process of helping individuals to accept and use information that can help them in their present problem or cope with it successfully ( Nasibi, 2002).

The Federal Republic of Nigeria (2004) recognizes the importance of guidance and counselling in the educational system at all levels. The National Policy of Education made guidance and counselling programmes compulsory at all levels of our school system in order to cater for educational, vocational and socio-personal worries of students in secondary schools in Edo State, Nigeria. The pertinent question is to what extend is comprehensive guidance and counselling programmes implemented in our secondary school system in Edo State, Nigeria? Also importantly, what is the relationship between comprehensive guidance and counselling and achievement outcomes of secondary school students in Edo State, Nigeria?; Is the relationship between comprehensive guidance and counseling and academic achievement of secondary school students in Edo State gender, school location and school type based? The researcher has no much knowledge in literature that holistically surveyed comprehensive guidance and counseling and academic achievement of secondary school students in Edo State, Nigeria. There is therefore a gap in knowledge. It is this gap in knowledge this study seeks to fill. This study will help to assess the relationship between comprehensive guidance and counselling and academic achievement of secondary school students in Edo State, Nigeria. Thus, the main thrust of this endeavour was to determine the relationship between comprehensive guidance and counselling and academic achievement of secondary school students in Edo State of Nigeria. The specific objectives of the study are: to determine if there is difference between male and female students in the influence of guidance and counselling on their academic achievement, to determine if there is difference between urban and rural secondary school students in the influence of guidance and counseling on their academic achievement and to determine if there is difference between public and private secondary school students in the influence of guidance and counselling on their academic achievement. 


\section{METHOD OF STUDY}

\section{Participants}

This was a descriptive correlational study based on survey research design to determine the relationship between comprehensive guidance and counselling and academic achievement of secondary school students in Edo State of Nigeria. Population consists of all secondary school students in Edo State. According to the Department of Research and Statistics of Post Primary School Board and Planning Department of Ministry of Education, Benin City (2019) the population of secondary school students in both public and private secondary schools in Edo State, Nigeria was two hundred and twenty thousand $(220,000)$ as of 2018/2019 academic session. The sample of the study comprised of two thousand and two hundred (2200) secondary school students in Edo State, which was one percent (1\%) of the population of the study. Multi-stage stratified simple random sampling was used in the sample selection of students from secondary schools in Edo State, Nigeria.

\section{Measure}

The research instrument that was used to gather data for the study was a questionnaire titled; "Comprehensive Guidance and Counselling Programmes and Students Academic Achievement Questionnaire (CGCPSAAQ)". It was design to elicit information from the respondents on comprehensive guidance and counselling and academic achievement of secondary school students in Edo State, Nigeria. The questionnaire was constructed by the researcher based on comprehensive review of literature. The instrument was made up of two parts, I and II. Part I consisted of three items which elicited demographic information on gender, school location and school-type of the respondents. There were twenty (20) items in part II which elicited respondents' responses on questions relating to relationship between comprehensive guidance and counseling and achievement outcomes of secondary school students in Edo State, Nigeria. The items on the research instrument were raised on a four (4) Likert scale on degree of agreement and disagreement with the statements or questions in the questionnaire. The scale was based on Strongly Agree $=4$, Agree $=3$, Disagree $=2$ and Strongly Disagree $=4$. The instrument (questionnaire) was content validated by two experts in test and measurement. Test-retest method was used to determine the internal consistency of the instrument. Thirty copes of the instrument were administered to secondary school students in Osun
States. These respondents were not part of the sample of the study to avoid pre-knowledge of items in the final work. The questionnaire was administered and re-administered to the selected students after two (2) weeks and score collated. Pearson Product Moment Correlation Coefficient (PPMCC) was used to correlate the scores. It yields to correlation coefficient (r) value of 0.74 . This shows that the instrument was reliable.

\section{Procedure}

The researcher administered the copies of the questionnaire with the help of five (5) research assistants who were specifically trained by the researcher for the purpose, secondary school teachers were employed as research assistants in order for them to bring their wealth of experience to bear in the administration and collection of data. The secondary school teachers (research assistants) were trained by the researcher on ways to carry out the exercise. The secondary school teachers (research assistants) that were engaged were secondary school teachers familiar with the terrain to assist in locating the schools during administration of the questionnaire. Each secondary school teachers was made to administer copies of questionnaire to respondents in two local government areas of Edo State. The researcher ensured that the purpose of the exercise was explicitly written on the questionnaire to facilitate the exercise. The researcher and research assistants took permission from the principal or heads of secondary schools and thereafter met the respondents in their various classes at the time of general recess. The purpose of the research was explained to the respondents and their cooperation in responding to the copies questionnaire solicited. The researcher and research assistants thereafter administered the questionnaires which were collected the same day. This was to ensure the copies of questionnaire were properly filled and returned. It took two (2) weeks to complete the exercise. Copies of the questionnaire were collected from the research assistants by the researcher following the completion of the exercise. The following statistical tools were used to analyse the data collected: percentage, mean standard deviation, t-test and Pearson Product Moment Correlation Coefficient (PPMCC).

\section{RESULTS}

Hypothesis 1: There is no significant relationship between guidance and counseling and academic achievement of secondary school students in Edo State, Nigeria

Table 1: Results of Relationship between Guidance and Counselling and Academic Achievement.

\begin{tabular}{|c|c|c|c|c|c|c|}
\hline Variables & $\mathbf{N}$ & Mean & SD & $\mathbf{r}$ & $\mathbf{p}$ & Remark \\
\hline $\begin{array}{l}\text { Guidance and } \\
\text { Counselling }\end{array}$ & & 22.87 & 4.81 & & & \\
\hline $\begin{array}{l}\text { Achievement } \\
\text { Outcomes }\end{array}$ & 2200 & 36.52 & 5.34 & .219 & 000 & Rejected \\
\hline
\end{tabular}


Table 1 showed that there was significant relationship between guidance and counseling and academic achievement of secondary school students $(r=.219, n=2200, p>.05$. The null hypothesis was rejected. Hence, guidance and counselling had significant relationship with academic achievement of secondary school students in Edo State, Nigeria.
Hypothesis 2: There is no significant difference between male and female secondary school students in the influence of guidance and counselling on their academic achievement.

Tables 2: Results of independent sample t-test on gender difference in the influence of guidance and counseling on academic achievement of secondary school students in Edo State.

\begin{tabular}{|llccccccc|}
\hline Scale & Gender & N & Mean & SD & Df & t & p & Remark \\
\hline $\begin{array}{l}\text { Guidance } \\
\begin{array}{l}\text { And } \\
\text { Counseling }\end{array}\end{array}$ & Male & 1000 & 49.2 & 8.44 & & & & \\
$\begin{array}{l}\text { Achievement } \\
\text { stutcomes }\end{array}$ & & & & & & & & \\
Outcomes & $\begin{array}{c}\text { Female } \\
\text { students }\end{array}$ & 1200 & 49.37 & 8.24 & & & & \\
\hline
\end{tabular}

Results from Table 2 indicated that there was significant gender difference in the relationship between guidance and counselling academic achievement of secondary school students in Edo State; Male (mean=49.25, SD=8.44), Female (mean=49.37, $\mathrm{SD}=8.24, \mathrm{p}=0.036)$. The probability value ( $\mathrm{p}=$ value) of 0.036 is less than 0.05 significant level. Based on the results in Table 2, the null hypothesis was rejected. This means that gender does have influence on the relationship between guidance and counselling and academic achievement of secondary school students in Edo State.

Hypothesis 3: There is no significant difference between urban and rural secondary school students in the influence of guidance and counselling on their academic achievement.

Tables 3: Results of independent sample t-test on location difference in the influence of guidance and counselling on academic achievement of secondary school students in Edo State.

\begin{tabular}{|c|c|c|c|c|c|c|c|}
\hline Scale & location & $\mathbf{N}$ & Mean & SD & $\mathbf{t}$ & $\mathbf{p}$ & remarks \\
\hline $\begin{array}{l}\text { Guidance } \\
\text { and } \\
\text { Counseling }\end{array}$ & $\begin{array}{l}\text { Urban } \\
\text { students }\end{array}$ & 1300 & 42.43 & 8.69 & & & \\
\hline $\begin{array}{l}\text { Achievement } \\
\text { Outcomes }\end{array}$ & $\begin{array}{l}\text { Rural } \\
\text { students }\end{array}$ & 900 & 32.30 & 8.19 & 1.915 & 0.043 & Rejected \\
\hline
\end{tabular}

Table 3 shows the results of the analysis of difference between urban and rural students in the guidance and counseling on their academic achievement. Urban (mean=42.43, $\mathrm{SD}=8.69)$, rural students $\quad$ (mean=32.30, $\mathrm{SD}=8.19, \mathrm{t}=1.915, \mathrm{p}=0.043)$. The probability value ( $\mathrm{p}=$ value) of 0.043 is less than the 0.05 significant level. Based on the result, the null hypothesis was rejected. The conclusion is that there was significant location difference in the influence of guidance and counseling and academic achievement of secondary school students in Edo State, Nigeria.

Hypothesis 4: There is no significant difference between public and private secondary school students in the influence of guidance and counseling on their academic achievement.

Table 4: Results of independent sample t-test on school-type in the difference in the influence of guidance and counselling on academic achievement of secondary school students in Edo State, Nigeria

\begin{tabular}{|lcccccccc|}
\hline Scale & School type & N & Mean & SD & Df & T & P & Remark \\
\hline $\begin{array}{l}\text { Guidance } \\
\text { and }\end{array}$ & Public & 1110 & 40.21 & 8.37 & & & & \\
$\begin{array}{l}\text { Counselling } \\
\text { Achievement }\end{array}$ & & & & & 2198 & 1.089 & 0.039 & Rejected \\
& & & & & & & & \\
\hline
\end{tabular}

Table 4 shows the results of the analysis of school type difference in the influence guidance and counseling on academic achievement of secondary school students in Edo State, Nigeria, Public (mean=40.21, SD=8.37), Private 
(mean=34.30.SD=8.06, $\mathrm{t}=1.089, \mathrm{p}=0.039$ ). The probability value ( $\mathrm{p}=\mathrm{value}$ ) of 0.039 is less than the 0.05 significant level. Based on the results the null hypothesis was rejected. The conclusion is that there was significant school type difference in the influence of guidance and counselling on academic achievement of secondary school students in Edo State, Nigeria.

\section{DISCUSSION}

The finding of the study revealed that there was significant relationship between guidance and counseling and academic achievement of secondary school students in Edo State. The finding of the study may be as a result of the provision or importance of guidance and counseling in the school system. The above finding agrees with the finding of Lapan et al (2003) and Hayes et al (2002).

The finding of the study indicated that there was significant gender difference in the influence between guidance and counselling on academic achievement of secondary school students in Edo State, Nigeria. The finding of the study corroborates the findings of Nwonyuku (2017)

The finding of the study revealed that there was significant location difference in the influence of guidance and counseling on academic achievement of secondary school students in Edo State, Nigeria. The finding may be as a result of the fact that there was location difference in the implementation of guidance and counseling services. This finding agrees with the finding of Sink and Stroh (2003).

The finding of the study indicated that there was significant school type difference in the influence of guidance and counselling on academic achievement of secondary school students in Edo State, Nigeria. This may be as a result of the fact that there was school type difference in the implementation of guidance and counselling services in secondary school in Edo State, Nigeria. The finding agrees with Bemak and Cornely (2002).

\section{CONCLUSION}

From the study, it can be concluded that there was a significant relationship between comprehensive guidance and counseling and academic achievement of secondary school students of Edo State, Nigeria. It can also be concluded that there was a significant difference in the influence of comprehensive guidance and counselling on academic achievement of secondary school students in Edo State, Nigeria based on gender, school location and school-type.

\section{RECOMMENDATIONS}

Based on the findings and conclusion of the study, the following recommendations were made:

Government at all levels should put in place comprehensive guidance and counselling programmes in all secondary schools in Edo State, Nigeria.
Qualified guidance counsellors who are the drivers of counselling programmes should be employed in all secondary schools in Edo State, Nigeria.

Guidance and counselling should be made an integral part of all secondary school students training in order to help them overcome their educational, vocational and sociopersonal worries or problems.

Association of Professional Counsellors of Nigeria (APPROCON) and Counselling Association of Nigeria (CASSON) should put appropriate mechanism in place aimed at ensuring full-fledged professionalization of counselling in Nigeria.

\section{REFERENCES}

[1] Alexitch, L.R.\&Page; 1 (1992). Evaluation of Academic and Career Counselling Information and its Relation to Students Education, Orientation. Canada Journal of Counselling, 31(3):205218.

[2] American School Counsellor Association (2005). Empirical Research Studies Supporting the Value of School Counselling. Retrieved https://www.schoolcounsellor.org/asca/media/asca/careersroles/effectiveness.pdf

[3] Armacost, R.L (1990). High School Stress and the Roles of Counselling. In School Counsellor, 38(2):105-112.

[4] Baker, S.B., \& Gerler, E.R, (2001). Counselling in Schools in D.C. Locke, J.E. Myer., and E.L. Her(Eds). The Handbook of Counselling, Thousand Oaks, C.A Sage Publications.

[5] Banathy. B.H.(1992). A System View of Education Concepts and Principle for Effective Practice. Englewood Cliffs NJ, Education Technology.

[6] Bemak,F. \& Cornely, 1.(2002). The SAFI model as a critical link between marginalized families and schools: A literature review and strategies for school counsellors. Journal of Counselling and Development, 80(3):322-331.

[7] Bogonko, S.N.(1992). Reflections Education in East Africa. Nairobi Oxford University Press.

[8] Bruce, M.A.\& Cockreham, D. (2004). Enhancing Spiritual Development of Adolescent Girls. In Professional School Counselling, 7(5): 334-342.

[9] Check, J.R., Beadley, I.J., Reynolds, J. and Cay, D. (2002). An intervention for helping elementary students reduce test anxiety. Professional School counseling 6(2):162-164.

[10] Erford, B.T., Bardhoshi, G., Ross, M., Gunther, C. and Duncan, K. (2017)." Meta-Anaysis of Counselling Outcomes for youth with Conduct Disorders" Journal of Counselling \& Development, 95(1):35-44.

[11] Ekundayo. D.O.S. (2019) Education in Nigeria is mass from top to bottom. Fine things can fix it. The conversation (the conversation.com

[12] Essuman, J.K.(2007). Guidance and Counselling in Basic and Secondary Schools in Ghana. Journal of Counselling, Education and Psychology,(2):142-143.

[13] Federal Republic of Nigeria (2004). National Policy on Education. Lagos: Federal Republic Nigeria Publishers

[14] Great School Partnership (2019). Students Outcomes. The Glossary of Education Reform.

[15] Hawkins, P. (2002).Understanding Management and Examination Practices. Nigeria; NERDC Press.

[16] Hayes s, R.I., Nelson, J., Tabin, M., Pearson, S. \& Worthy, C. (2002). Using School-wide data to advocate for student success. Professional School Counselling, 6(2):86-95.

[17] Jones, R.(2001). Suicide Watch: What can you do to stop children from killing themselves. American School Board Journal May, 1621. 
[18] Lapan, R.T., Tucker, B. Kin, S. \& Koschilek, J.F. (2003) Preparing rural adolescents for post-high school transition, Journal of Counselling and Development, 81(3):329-342.

[19] Nasibi, W.M.W. (2003), Discipline: Guidance in Schools in Nairobi. Strong wall Africa

[20] Nwonyuku, K. (2017). Impact of Guidance and Counselling on performance of secondary schools in Awka South Local Government Area of Anambra State, Nigeria, National Teachers Institute, Kaduna, Kaduna State Nigeria.

[21] Okobiah, O.C.\& Okorodudu, R.I.(2004). Concepts of guidance and counselling. In issues, concepts, theories and techniques of guidance and counselling. Benin city: Ethiope Publishing Corporation.

[22] Olayinka, M.S (2001). Counselling needs of the adult learner. Nigeria: Jaja Printing Press.

[23] Schaefer-Schriumo, k. \& Ginsberg, A.P (2003). The effectiveness of the warning signs program in educating youth about violence prevention: A study with urban high school students. Professional School Counselling, 7(1):1-8.
[24] Sink, C.A.\& Stroh, H.R., (2003). Raising achievement test scores of early elementary school students through comprehensive school counseling programs. Professional School Counselling, 6(5)350364.

[25] Spark Notes Editors. "Spark Notes: The Great Gatsby." Spark Notes.com, 2005. December 12, 2019.

[26] Standard, R.P. (2003). High school graduation rates in the United States: Implications for the counseling profession. Journal of Counselling and Development, 81(2):217-224.

[27] Student Poll (2000). Art \& Science Group, Inc. 4:2,1-10. Available at http//www.artsci.com

[28] UNESCO (2000) Module 8. Guidance and Counselling Programme Development Botswana.

[29] Van, D.W. and Knoetse, I. (2004). Violence as an Impediment to a Culture of Teaching and Learning in some South African Schools. South African Journal of Education vol. 24 (2) 11-17.

[30] Whiston, S.C., Tai, W.L., Rhardja, D. and Eder, K. (2003). "Does treatment modality affect career counseling effectiveness? 